\title{
Dropout and Engineering undergraduate programs at the Universidad Nacional de Colombia between 2012-2019
}

\author{
Mónica Sánchez-Nítola ${ }^{1}$, Diana M. Grijalba ${ }^{1}$, Manuel Embus ${ }^{2}$, Andrés Suarez ${ }^{1}$, Juan
} E. Guevara ${ }^{3}$

${ }^{1}$ Human Sciences School, Universidad Nacional de Colombia, Colombia, ${ }^{2}$ Engineering School, Universidad Nacional de Colombia, Colombia, ${ }^{3}$ Sciences School, Universidad Nacional de Colombia, Colombia.

\begin{abstract}
Dropout is a topic of significant concern to Higher Education Institutions, especially in Colombia it is considered one of the most important indicators to define higher education quality. Nevertheless, in Colombia, and particularly at the Universidad Nacional de Colombia, it has been generally assessed only academic dropout. This decision has prevented understanding other types of dropouts that also occur in the university. The research group performed Multiple Correspondence Analysis to assess the relationship between dropout types (academic, dropout on request, and expiry of time limits) and variables such as sex, socioeconomic stratum, type of admission, and semester of dropout. In the results, we found a disparity between types of dropout concerning the type of university admission, sex, socio-economic stratum, and the semester in which dropout occurs. Women are related to the dropout request while men are associated with the academic dropout. Additionally, the academic dropout occurs in the first 4 semesters, and the expiry of time limits occurs in the last ones.
\end{abstract}

Keywords: Dropout types; engineering undergraduate programs; socioeconomic stratum; sex; semester, type of admission. 


\section{Introduction}

In higher education and developing countries, dropout has been a topic of significant concern. For instance, Colombia has the second highest dropout index in Latin America (Ferreyra et al., 2017). This phenomenon has been also considered by the National Accreditation Council of Colombia; thus, dropout is one of the most important indicators to determine the quality of a higher education institution.

For the Colombian Ministry of National Education (2009) dropout occurs when the student stops their curricular program and does not register for two continuous periods. On the other hand, at the Universidad Nacional de Colombia (UNAL from now) (2008), a student can be considered as a dropout if after three consecutive years they do not re-entry the academic program. In both cases, to define desertion it is necessary to consider the determinant factors of this phenomenon, among which are individual socioeconomic conditions, academic skills, institution resources and individual variables (motivation, health, among others). Additionally, the academic abandonment can be classified according to the reasons for which it occurs: Voluntary or involuntary; related to the moment in the program in which it is presented: premature, early or late; or depending on whether it is temporary or permanent (Castaño et al., 2004; Ramirez et al., 2016).

\subsection{Dropout at Engineering undergraduate programs at Universidad Nacional de Colombia}

Notwithstanding the Engineering school's good results at national (Revista Dinero, 2018) and international rankings (QS Quacquarelli Symonds Limited, 2019), it has not been immune from academic abandonment. Whereas the academic dropout rate of engineering school has decreased and is lower than other schools at UNAL (Oficina de Planeación y Estadística Sede Bogotá UNAL, 2019), numbers are still high (range from $32.4 \%$ to $65.4 \%$ ). Those rates are problematic considering that dropout can have serious social, economic and academic consequences for both dropouts, educational institutions, the country and society (Patiño \& Cardona, 2013; Torres, Acevedo, \& Gallo, 2015).

\subsection{Research goal}

The analysis presented in the present paper aims to characterize the dropout in the Engineering School at Universidad Nacional de Colombia, between 2012 and 2019. 


\section{Methodology}

To characterize the dropout in the School of Engineering at UNAL from 2012 to 2019, we consulted the institutional databases and obtained variables such as Type of admission ${ }^{1}$, Semester of dropout, Sex and Socioeconomic stratum ${ }^{2}$. Besides, we had to construct the variable Status, which refers to the differents ways of blocking an academic record. For example, in the first place, there is Academic dropout which occurs in two cases: having a GPA average of less than 3.0 on a scale from 0.0 to 5.0 or lacking the necessary number of credits to complete the program. In the second place, there is Expiry of time limits, where the student stops attending or paying for the tuition at the University without giving notice. In the third place, some students apply for readmission, change or withdraw from the program, and transfers to another campus, which is called Dropout on request.

To achieve a detailed description of dropouts, Matlab ${ }^{\circledR}$ computer system was used for performing various multiple correspondence analyses (MCA) between all variables and types of dropout (Status). Besides we used a k means analysis to determine the number of clusters in each MCA graphics.

\section{Results}

\subsection{Demographic characteristics and dropout}

In the window of time studied, on the one hand, women admitted to the School of Engineering only represented $17 \%$. They were characterized by being mostly from stratum $3(41 \%)$. On the other hand, men represent $83 \%$ of the population of the School of Engineering and they mostly belong to stratum 1 and 2 (37\% in both cases).

\subsection{MCA results}

In Figure 1, each MCA graphic has a variance explanation above 80\%, which means great power in the relations drawn. Besides, dimension 1 explains more variance in all graphics.

As shown in Figure 1, the Academic dropout is more related to males who were between the semester 0 to 4 , especially to those who live in socioeconomic strata 1 to 3 or in non-

\footnotetext{
${ }^{1}$ The regular admission implies a minimum score in the university exam. The Special Admission Program (now PAES because of its Spanish initials) privileges vulnerable groups (indigenous communities, Afro-Colombian, victims of the non-International Armed Conflict in Colombia, among others). The Special Admission and Academic Mobility Program (from now on PEAMA because of its Spanish initials) is a strategy of the institution to link more high school graduates from all over the country to higher education.

${ }^{2}$ Each city in Colombia is divided into 6 socio-economic strata, which respond to a classification of residential properties. This differentiation is made especially for the collection of public services, allocating subsidies to the lower strata (1-3) and collecting contributions from the high strata (4-6) (Marcos, 2018). Non-stratified houses correspond to indigenous reserves.
} 


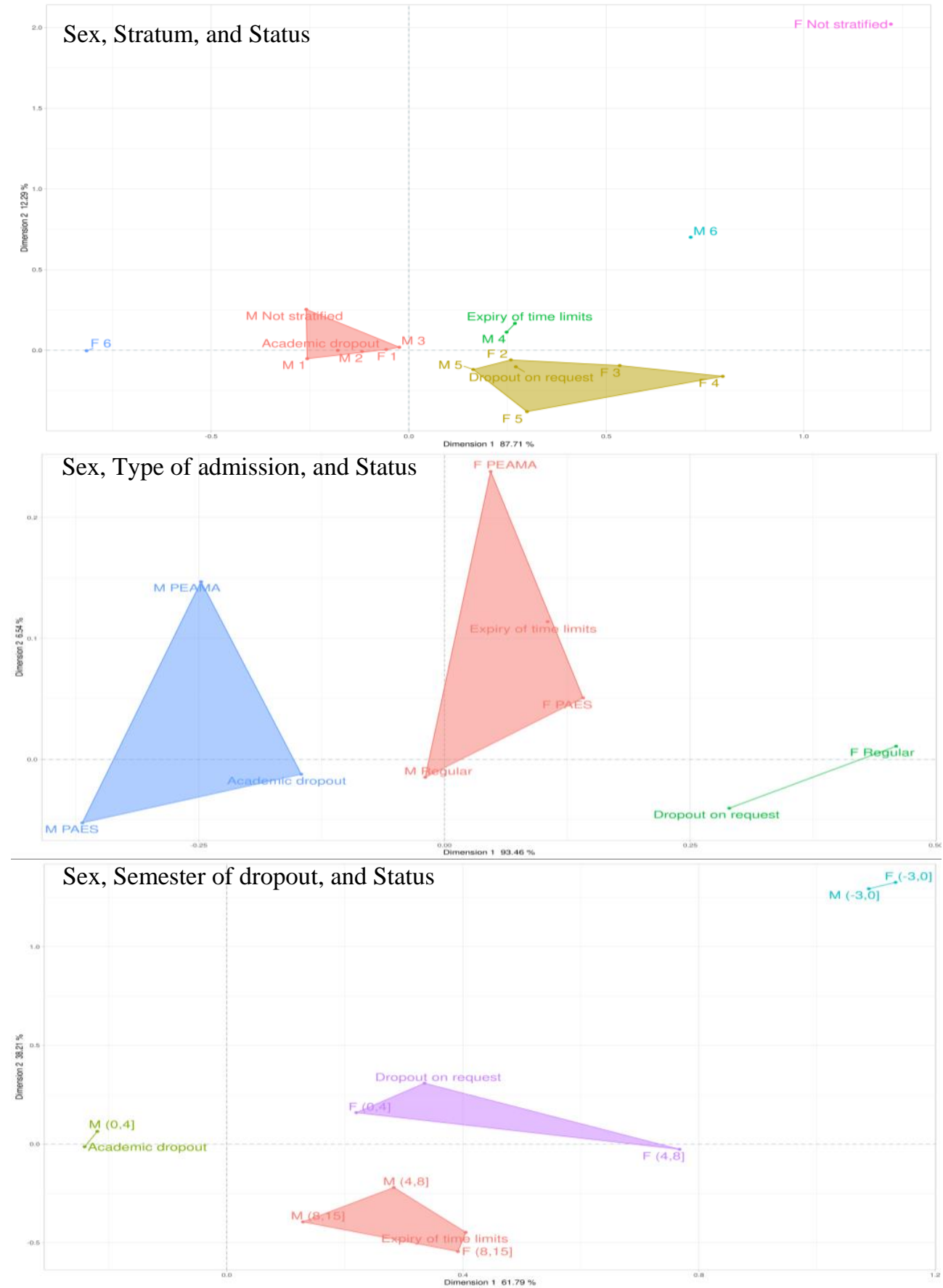

Figure 1. Multiple Correspondence Analyses 
stratified houses, and to those who were admitted by PEAMA and PAES type of admission. Only women who live in strata 1 are strongly related to academic dropout. Furthermore, the dropout on request is related to women at semesters 0 to 8 , who live in stratum 2 to 5 . Moreover, females with regular admission were associated with this type of dropout, but only men who live in stratum 5 were strongly associated with dropout on request. Finally, the expiry of time limits is mostly related to women in semesters 8 to 15 , and with PEAMA and PAES admission. Additionally, this type of dropout is associated with males who reported to live in stratum 5 , are between semester 4 to 15 , and had a regular type of admission.

\section{Conclusion}

One of the most evident results is that each status is related to a specific group of semesters. For example, we can state that the academic dropout generally occurs in the first four semesters of the programs. Furthermore, expiry of time mostly occurs in the last semesters, between semesters 8 and 15. Additionally, dropout on request occurs between semesters 0 and 8 only for women. The first case could be explained by the high academic demands during the first semesters: in all engineering programs, the basic or foundation courses in mathematics and physics must be taken, therefore, there is a greater probability of losing the course and deserting due to low academic average. Other studies in the UNAL have shown that students at first semester have a higher risk of dropping out than those at other semesters (Gallego, 2014). Notwithstanding, a contribution of this study is that other types of dropouts were evaluated and, with these preliminary results, the differences in their behavior can be observed. This opens the possibility to deepen the explanations to these differences in the following phases of the study.

People's chances of entering higher education are directly related to their social origin, depending on many factors, such as the sex, socio-economic level, among others (Bourdieu and Passeron, 2009). Results also showed that women who enter at the School of Engineering have better socio-economic conditions compared to men, since they come from higher strata. Arango (2006) calls this situation as the relative social and academic over-selection of women in Engineering. Therefore, as we corroborated with this result, permanence in high education is also strongly affected by the social conditions of the people.

We found that the dynamics of the dropout is relative to this over-selection. Voluntary abandonment is produced when the student renounce, without notice, to the University, while involuntary abandonment occurs when the student has not good academic performance and withdraw from the university because he/she does not meet the demands (Himmel, 2012). In this sense, it seems women can abandon the program in a volunteer 
way (dropout on request) and men, due to his infra-selection, present involuntary abandonment of the program (Academic dropout).

These are preliminary results and it is necessary to determine factors of dropout and to dialogue with people who dropout and with those who are at risk, in order to explore their experiences with this problem. With those tools, the Faculty Board could make decisions, identify the probability of dropout of those at risk, and control some of the factors related to this phenomenon that are under its governance.

\section{References}

Arango, L. G. (2006). Género e ingeniería: La identidad profesional en discución. Revista Colombiana de Antropología, 42, 131-156. Retrieved from http://www.scielo.org.co/scielo.php?script=sci_arttext\&pid=S048665252006000100005\&lng=en\&tlng=es.

Bourdieu, P., \& Passeron, J. (2009). La elección de los elegidos. En P. Bourdieu, \& J.-C. Passeron (Eds.). Los Herederos, pp.12-45. Buenos Aires: Siglo veintiuno editores.

Castaño, E., Gallón, S., Gómez, K., \& Vásquez, J. (2004). Deserción estudiantil universitaria: una aplicación de modelos de duración. Lecturas de Economía (60), 3965. Retrieved from: https://www.redalyc.org/pdf/1552/155217798002.pdf

Colombian Ministry of Education. (2009). Deserción estudiantil en la educación superior colombiana. Metodología de seguimiento, diagnóstico y elementos para su prevención. Retrieved from https://www.mineducacion.gov.co/sistemasdeinformacion/1735/articles254702 libro_desercion.pdf

Ferreyra, M. M., Avitabile, C., Botero Álvarez, J., Haimovich, F., \& Urzúa, S. (2017). At a Crossroads: Higher Education in Latin America and the Caribbean. Washington, DC: The World Bank.

Gallego, L.E. (2014). Evaluación de la reforma académica en programas de pregrado de la Universidad Nacional de Colombia. Dirección Nacional de Programas Curriculares de Pregrado.

Himmel, E. (2002). Modelos de análisis de la deserción estudiantil en la educación superior. Revista Calidad en la Educación (17), 91- 108. doi: http://dx.doi.org/10.31619/caledu.n17.409

Marcos, A. (22 de Abril de 2018). Los estratos en Colombia: eres el lugar en el que vives. El país.

Universidad Nacional de Colombia. (2008). Acuerdo 008 de 2008, Estatuto estudiantil. Retrieved from: http://www.legal.unal.edu.co/rlunal/home/doc.jsp?d_i=34983

Oficina de Planeación y Estadística Sede Bogotá Universidad Nacional de Colombia. (2019). Deserción. Retrieved from: http://planeacion.bogota.unal.edu.co/y9vkWipGjuD8-14.html

Patiño, L., \& Cardona, A. M. (2013). Review of some studies on university student dropout in Colombia and Latin America. Acta Universitaria, 23 (4), 37-46. Retrieved from: https://www.redalyc.org/pdf/416/41628340005.pdf 
QS Quacquarelli Symonds Limited. (2019). QS World University Ranking. Elsevier. Retrieved from https://www.topuniversities.com/university-rankings/university-subjectrankings/2019/engineering-technology

Ramirez, T., Díaz Bello, R., \& Salcedo, A. (2016). El Uso De Los Términos Abandono Y Deserción Estudiantil Y Sus Consecuencias Al Momento De Definir Políticas Institucionales. Congresos CLABES. Recuperado a partir de https://revistas.utp.ac.pa/index.php/clabes/article/view/1391

Revista Dinero. (24 de mayo de 2018). Las mejores universidades en ingeniería en Colombia 2018. Revista Dinero. Retrieved from: https://www.dinero.com/edicionimpresa/caratula/articulo/ranking-de-mejores-universidades-en-ingenieria-de-colombia$2018 / 258763$

Torres, J. D., Acevedo, D., \& Gallo, L. A. (2015). Causas y consecuencias de la deserción y repitencia escolar: Una visión general en el contexto latinoamericano. Cultura Educación y Sociedad, 6 (2), 157-187. Retrieved from: https://revistascientificas.cuc.edu.co/culturaeducacionysociedad/article/view/904 